\title{
Civil Society's Role in Operating and Managing Good Governance in Nepal
}

\author{
Lecturer, Kapilmani Dahal, PhD Scholar \\ Department of Political Science, Tribhuvan University, Prithvi \\ Narayan Campus, Pokhara, Nepal
}

\begin{abstract}
Civil society is non political sphere and individual made voluntary organization widely understood as the space outside the family, market and state. It is associated for welfare of state on the ground of civic knowledge, civic education and civic virtue. Civil society works and plays its role in the democratic regime. Democratic regime operates on the basis of democratic norms and values. Civil society plays roles in the democratic society relating to maintaining, promoting and strengthening good governance. It plays various roles like participating, mediating interest, mobilizing counter knowledge, influencing policy making, building commitment for public good, giving impetus to community building projects, motivating citizens, government towards co-operation, etc. It can play the communicative role, protective role, control role, socialization role, service delivery role and the global citizenship role in different cases. Major areas of good governance are democracy, rule of law, proprietary rights, corporate governance, human rights, welfare state and labor institution. And in these areas civil society can perform their respective roles. In the case of Nepal some roles have been managed under constitution and statutory law mainly in good governance operation and management act. But these provisions seem inadequate for showing their role visibly. Maintaining good governance through properly implementing fundamental rights, government has not made effective laws yet. Nepalese parliament has promulgated the act named good governance operation and management act 2008. Here some provisions relating to civil society's role in operating and managing process has been mentioned. In this article constitutional role as well as legal role has
\end{abstract}


been taken in due consideration because civil society's constitutional and legal roles have not been duly recognised yet. Thus the study has given imphasis on description and analysis of content relating to civil society 's role managed under the costitution and statutory law act. To draw the conclusion in this study descreptive-analytical and content analysis methods has been used and information has been taken from secondary method. constitution of Nepal and good governance operation and management act 2008 have been taken as major contents for analysis of civil society's role in managing and operating good govenance in Nepal.

Keywords : Civil society, constitution, democracy, good governance, rule of law.

\section{Introduction}

Civil society is the back-bone of the democracy and incorporates according to the concept of plurality of society. According to Clayton (1996), "CSOs" (civil society organizations) as diverse forms of organizations exist outside the state and the market to provide counterbalancing functions to both the state and the market (Clyton, 1996:7). Migdal considers "civil society" as a group that is freely created on the basis of common interest to serve as a bridge between society and government (Migdal, 1988:13). Similarly, Gramsci refers to "civil society" as those groups which are freely organized outside of the political sphere on the basis of common interests and which work towards protecting their relative autonomy and realizing the interests and wishes of their members (Gramsci, 1971:11). A definition of "civil society" by the London School of Economics views it as an arena of unforced collective action around shared interests, purposes and values, whose institutional forms are distinct from those of the state, family and market - though in practice the boundaries between state, civil society, family and market are often blurred and negotiated (Anheier2000:6-8). All these 
definitions and concepts make it clear that civil society is an inevitable element in the society.

Civil society is generally voluntary organizations associated for welfare of state. It is associated on the ground of civic knowledge, civic education and civic virtue. Civil society works and plays prominent role in the democratic regime. Democratic regime operates on the basis of democratic norms and values. Such norms and values are incorporated in the Constitution of Nepal too (Preamble the constitution of Nepal). Constitution is a means of providing place for civil society. In totality, the constitution which has not provided sufficient place for civil society cannot be run for a long time. Provision of freedom of association is basic foundation forming civil society. Unions, associations, organizations, institutions and all networks can be included within the scope of civil society. In the case of assimilation of civil society people can engaged for the welfare of society. Civil society can be perform their effective work in the decision making and implementing process. Civil society teaches citizens on participation of people on democratic system. It can easily check on the performance of political parties and make them responsible to people. Civil society checks and controls the action of government contrary to the interest of people. Civil society preserves the democracy but insufficient constitutional provisions can not help functioning it very well. Sufficient constitutional provisions benefit both the government and the society. But it is also true that but inactiveness of civil society hampers the democracy and people's rising aspirations.

Civil society plays various roles in the society. Among them the role relating to maintaining, promoting and strengthening good governance is considerable for implementing democratic governance. In the context of Nepal too our constitution has 
provided some space for civil society. Although, the needy legal provisions for implementing constitutional provisions relating to good governance has not been properly managed as yet. Nepalese parliament has promulgated the act named good governance operation and management act 2008. Here some provisions relating civil society's role in operating and managing process has been mentioned. In this article constitutional role as well as such legal role have been trying to mention.

\section{Objectives and Methodology}

Civil society and good governance are two important terminologies used frequently in day to day life. Both have various connotations but in political field generally civil society denotes voluntary organization organized for welfare of state and good governance. This study has focused civil society's role in operating and managing good governance. Here generally two roles (constitutional and legal role of civil society) have been shown by respective content analysis. So in this study two major objectives have been determined. Firstly to show the roles and functions of civil society in general and secondly to show the constitutional and legal provisions relating to civil society's role managed in Nepal. Research methodology as the process and way of resolving problem in the course of study here secondary data and information have been used. Library sources have been taken as storehouse of knowledge and bank of information to describe and analyze the subject. The constitutions of Nepal and good governance operation and management act have been taken as major content for descriptive-analytical methods. Various books, journals, reports, research articles, websites have been used to get qualitative information. 


\section{Roles and Functions of Civil Society}

Civil society is an arena where manifold social movements and civil society organizations from all classes, attempt to constitute themselves in an ensemble of arrangements, so that they can express themselves and advance their interests (Bratton, 1989:417).

Civil society has its various notions. It is public realm between sate and family, different from political society, theoretical construct than empirical, as the source of legitimacy, and civil society and state are distinct but best considered together. The objective of this study is not defining civil society but showing its roles and functions. This is why, only roles and functions have been mentioned here.

Civil society is very closest organization, movement, initiative and individual for solving problems and strengthening democracy through implementing good governance. Civil society organizations hold government accountable for their duty to fulfill the right to education. Parent's association, children's association, youth association, teacher unions are some examples of education relating to civil society (www.globalparternership. org). Civil society is an idea that affects every one in every nation (www.bbcworldservice.co.uk). The paradox about civil society is that it covers a vast range of activities -it is very hard to define. Civil society is a public space between the state, the market and the ordinary house hold, in which people can debate and tackle action. Civil society has a political dimension but not political parties.

Civil societies do not seek political power for themselves. Civil society can do various works to nurture the concept of democracy. The first and basic role of civil society is to limit and control the power of state. Civil society actors should watch 
how state officials use their powers. They should raise public concern about any abuse of power. They should lobby for access to informing including free information laws and rules and institutions to control corruption (www.webstandford.edu ).

Such as second important function of civil society is to expose the corrupt conduct of public officials and lobby for good governance reforms even where anticorruption laws exist, they can't function effectively without active support and participation of civil society. Third function of civil society is to improve political participation. Forth, civil society organizations can help to develop the other values of democratic life. Fifth, civil society also can help to develop programs for democratic civic education in the schools as well. Sixth, civil society is an arena for the expression of diverse interests, and one role for civil society organizations is to lobby for the needs and concern of their members as women, students, environmentalisms, trade unions, lawyers, doctors, etc. NGOs and interest groups can present their views to parliament, they can dialogue with relevant government ministries. Seventh way of civil society can strengthens democracy by new form of interest and solidarity. Eighth, civil society can provide a training ground for future political leaders. Ninth, civil society can help to inform the public about important public issues. Tenth, civil society organizations can play an important role in mediating and helping to resolve conflicts. Eleventh, civil society organizations have a vital role to play in monitoring the conduct of elections. Civil society is a check, a monitor but also a vital partner in the quest for positive relationship between the democratic state and its citizens (www. webstandford.edu)

The pluralistic group of civil society and its types and functions have been well elaborated by Diamond (1994). They are in short: 
economic, cultural, informational, and educational, interestbased, developmental, issue-oriented and civic (Diamond, 1994:6). Civil society commonly strives for autonomy from the political and economic societies to redress inequality, injustice and multiple forms of domination in society. It also upholds a model of social movements against distributional, legitimating and devolution crisis induced by new hegemonic formation; that has initiated new forms of operation, transmission of a dominant culture and subordination of citizens into contemporary capitalist societies (Gladwin, 1994:62). The emerging ecological, peace, indigenous, poor, women and civil society movements are the results of historical and spiritual manifestation against the organizational control of the material world (Dahal and Bongarz, 2008:64).

Civil society organizations play an important role in public budgeting. They can help improve budget policies through providing information on public needs and priorities through their connections with citizens, communities and sectors. Civil societies also can play an important role in holding the executive accountable for how it uses public resources. When civil society can combine an in-depth knowledge of policy issues and do effective advocacy then they can positively influence policy decisions.

Paffenholz (2009) explores- civil societies' role on peace building which is relating to good governance also because good governance can't be maintained without peace and harmony in the country. On the other hand the similar role of civil society in the peace process can be linked to maintaining good governance. Civil society is widely assumed to be an important factor for peace building. As such substantive focus has been given towards building and strengthening civil society especially in 
countries experiencing or emerging from situation of armed conflict. In such environments civil society is understood as playing an important role in reducing violence and in facilitating the conditions necessary for building a sustainable peace.

Civil society has seven functions. These functions are: protection, monitoring, advocacy, socialization, social cohesion, facilitation, and service delivery. It shows that civil society can play an important supportive role though the impetus for peace building comes in most cases from political actors and the conflict parties themselves. On the whole, protection, monitoring, advocacy and facilitation related activities were of higher effectiveness, whereas socialization and social cohesion related activities were of low effectiveness across all cases. It is also found that there is a significant importance in recognizing other contextual factors that may limit or strengthen civil society's ability to fulfill a peace building roles. Contextual factors include: the behavior of the state, the level of violence, the role of the media, the composition of civil society, and the involvement of external political actors and donors (Paffenholz, 2009:2-3).

Dahal (2006) writes on -Civil Society Groups in Nepal, Their Roles in Conflict and Peace Building. He mentions that urban and rights based civil society received an additional boost from the western aid regime with its agenda for the promotion of democracy. This was buttressed by the ballooning of public expectations regarding a distributive state and rights- based development. Civil society is today taken as a conduit for democratization, leadership change, economic liberalization, good governance and peace building. This idea assumes civil society to be 'purely instrumental process whose parameters were decided by donors and which turned many NGOs, indigenous people's institutions and social organizations into 
projects (Dahal, 2006:4).

Many civil society groups registered with SWC, however, are given the mandate to work on relief, charity, environment protection, economic projects and social development rather than on political education and conflict resolution. He concludes pitting democracy versus the state, human rights against security responsibilities, professionalism versus political alliance, tradition versus modernity, men versus women, or one class, cast, ethnic groups or race against the other will not ever resolve the conflict in Nepal, The very fact that attempts surface from time to time to show the conflict in this light means that there are active interests which see the conflict as an opportunity rather than a challenge to be resolve (Dahal, 2006:32).

Diamond proposes a twelve item list for assessing democratic functions of civil society which are also indispensable and important for good governance.1. Checking, limiting and monitoring the power of the state. 2) Supplementing the role of political parties in stimulating participation. 3) Development of democratic attributes through education. 4) Providing multiple channels for interest representation beyond political parties. 5) Mitigating principal polarities of political conflict and hence surpass clienteles. 6) Generating cross cutting interests that will mitigate the political polarities. 7) Recruiting and training new political leader. 8) Creating organizations with explicit democracy-building goals (for example election monitoring). 9) Disseminating information and idea. 10) Providing basis for reform policies. 11) Conflict mediation and resolution and 12) Enhancing the accountability, responsiveness, inclusiveness, effectiveness, and hence legitimacy of the political system by fulfilling above listed items (Diamond, 1999:239-250).

Civil society can work for protection and promotion of democracy 
and development. Democracy as nation's power and legitimacy gained from the people's freedom, democratization of state and society. Availability of opportunity can be obtained by roles of civil society played in the society. Civil society's role becomes important in establishing, developing and strengthening powerful and effective democracy. For it working for building popular mandate against all forms of authoritarian and arbitrary political system, working for commitment building by state structures and political parties in favor of civic freedom, democratic process and democratic rights, working in reforming political parties, building consensus in political improvement, resolving conflict, holding public debates and working for participation like building in election, assisting to dialogue between people and government, creating environment, participating in governance system, capacity building, legitimizing consensus in constitutional and legal matters are remarkable in democratic and development process.

Civil society can play roles regarding advocacy, watchdog, networking, role regarding research, supporting in technical areas and other co-coordinating and representing roles. Functions of checking, monitoring and restring the government's exercise, functions of training and empowering the community, functions of channel for affecting decision makers and functions serving of school of democracy for fostering democratic culture are also related to civil society's in roles maintaining good governance.

\section{Constitutional and Legal Role of Civil Society}

Civil society can be conceived as a social and public space and sphere that is above the domain of family and below the state. Insofar as the role of civil society in governance is concerned this is important particularly for having good governance. Without an active civil society, the prevalence and institutionalization of good 
governance is not possible. Civil society is an important aspect of democratization process. It provides an environment that can be used to enhance community cohesion and decision-making. Civic participation is important in decision making. When people get better informed, they are most likely to participate in policy discussions, decision making and communicate their ideas and concerns freely.

The role of civil society in good governance is to apprise people of their fundamental rights and responsibilities. In addition, civil society is instrumental in making people aware about the role of the government and state institutions. Moreover, civil society provides the forums to the people to debate and discuss their issues and communicate them to the rulers and administrators. Civil society also provides the platforms to the people to maximally participate in the process of governance. Civil society is also critically important for making people aware of the need and value of the rule of law, as well as apprising government institutions and functionaries of the state about the importance and their respective role(s) in ensuring the rule of law. (khan, 2018). There is now broad consensus that good governance requires both a strong state and a strong civil society (Matena, Carmen: 2010).

Good governance, generally, encompasses a broad array of practices that maximize common good. Some of the attributes of good governance are democratic practices, rule of law, and respect for human rights. In Nepali context, Nepalese civil society seems divided and affected by party politics. Only a few numbers of civil society members are playing and showing their independent roles. Others are either adopting culture of silence or advocating as being spokes person of political parties. All these have shadowed good governance in Nepal. 
Civil society and good governance have become as ideal terminologies in Nepali context too. Both have been used differently time to time, place to place and persons to persons everywhere. Generally they are thought ideal and are true too for some limitations but they are not ideal only but are practical subjects executing day to day life of peoples. But one concern is that before implementing them, there should be made adequate provisions relating to civil society's roles in maintaining good governance for strengthening democracy. Unless constitutionally or legally made such provisions, civil society's role in good governance can't be seen visibly. So here some provisions relating to civil society's role made in the constitution and law act about maintaining good governance have been mentioned.

\section{Constitutional Roles of Civil Society}

Constitution is major ends as well as means governing the nation's politics. It is guideline, blueprint or directives handling nation's major governmental institutions. Constitution provides more or less space for other arena and structures of politics. Civil society is one of the aspects of political and some of its roles have been mentioned in the constitution of Nepal. This constitution was participative constitution and was made on the context of universally institutionalizing the concept of the supremacy of constitution, constitutionalism and good governance. This constitution is the product of civil society's movement in 2006. So there can be seen the reflection of the civilian movement in the interim constitution and the constitution had made some provisions relating to civil society directly or indirectly.

The preamble of the constitution starts 'we the sovereign people of Nepal'. It indicates that civil society can affect the proper implementation of the constitution. On the other hand the provision of vesting the sovereign as well as the state power in 
the people respects the presence of civil society in the state. The constitution has accepted the norms and values of democracy as unity in diversity, tolerance, solidarity, equality and equity, social justice, equitable society, participatory system, full freedom of press, fundamental rights and their effective way of guarantee, human rights, independent judiciary, rule of law, periodic election and civic liberties (Interim Constitution of Nepal: 2007) are directly related to the playing roles of civil society in the state according to the constitution of Nepal.

Constitution of Nepal 20015 has also incorporated various provisions relating to civil society role in good governance system. The roles of civil society incorporated in this constitution are similar to the provisions incorporated in the interim constitution of Nepal 2007, so the provisions incorporated in that constitution have been mentioned above for its reference but not for comparison. Constitution as the fundamental law (article, 1), sovereignty and state authority of Nepal vested in the Nepalese people (article, 2), Nepal as an independent, sovereign, inclusive, democratic socialism oriented federal democratic oriented state (article, 4), basic features of national interest of Nepal as sovereign state (article, 5) are the civil society related provisions managed under part 1 the preliminary of the constitution of Nepal.

The constitution of Nepal has included the very important part, part 3 under the provision of fundamental rights and duties. There is provision of life with dignity (article, 16). The constitution included right to freedom and under it, the constitution provides freedom of opinion and expression, freedom of assemble peaceably and without arms, freedom to form unions and associations (article 17(a, b, d) except some exceptions i.e. against sovereignty, territorial integrity, nationality and independence of 
Nepal or the harmonious relations between the federal units or the people of various castes, tribes, religions or communities or incite caste-based discrimination or untouchability or on any act of disrespect of labor, defamation, contempt of court, incitement to an offence or on any act which may be contrary to public decency or morality are directly related to the presence of civil society in the state. Such as right to equality (article, 18) treats all citizens shall be equal before law. No person shall be denied the equal opportunity of law.

It is also seems the prerequisite for civil society to raise the voice for the equality of the people in the state. Right to communication (article, 19) which is correlated to freedom of opinion and expression is the most important provision made for civil society in the constitution because no member of civil society can raise the voice in the society without this provision. The constitution reads- no publication and broadcasting or dissemination or printing of any news item, editorial, feature article or other reading, audio and audio-visual material through any means whatsoever including electronic publication, broadcasting and printing shall be censored except some limitations as mentioned before.

It is very important for the function of civil society to educate and aware the people. There is a provision in the constitution about limiting this right to communication. Mentioning in the constitution that no means of communication including the press, electronic broadcasting and telephone shall be interrupted except in accordance with law, has made us doubt that if government made law for restricting the right to communication then civil society should be stayed with silence in the society but taking the assistance of other provisions made in the constitution making effective implementation of constitution and making 
the supremacy of constitution, supreme court can ultraviolet the inconsistent provisions made by government as well as parliament and civil society can act properly. Right to demand and receive information on any matter of his or her interest or of public interest (article, 27) and the privacy of any person, his or her residence, property, document, data correspondence and matters relating to his or her character shall, except in accordance with law, be inviolable (article 28) which are interrelated to provisions right to freedom of expression of opinion and thought and right to communication for the effective presence of civil society in the state.

The arrangement relating to right to constitutional remedy has been made in the article 46 of the constitution. According to the constitutional provision, constitutional remedy can be obtained applying the provisions made under article 133 and 144 of the constitution which is significant to the provision of civil society. These provisions made in the constitution are significant for maintaining and strengthening good governance for democratic polity. On the basis of these provisions relating to fundamental rights, civil society can play their roles for implementing good governance. Constitution has arranged some provisions regarding some constitutional organs and commissions. So living in the constitutional organs civil society can play crucial role implementing good governance. Constitutionally provisions relating to human rights, fundamental rights, rule of law, independent judiciary are basic pillars of good governance and these provisions have been provisioned in the constitution; how ever, there are some hurdles implementing the fundamental rights. 


\section{Legal Roles of Civil Society Made under Good Governance Operation and Management Act 2008}

Good governance is an end and to reach there, various steps are to be crossed everywhere. In Nepal too to maintain and strengthen good governance the special act named 'Good Governance Operation and Management Act 2064' B.S. has been made and implemented too. Major Provisions relating to the role of civil society for operating good governance made in this act are mentioned below:

\section{Preamble}

This act was made and promulgated in 2064 B.S. to guarantee (ensure) good governance in Nepal and it has amended two times in 2072 and 2075 B.S.. The act focuses public administration as mechanism of providing good governance. In the preamble the elements of good governance has clearly mentioned. It also emphasized good governance as people's right obtaining in practicability.

It reads- whereas, it is expedient to make legal provision in relation to good governance by making public administration of the country pro-people, accountable, transparent, inclusive and participatory and make available its outcome to the general public; upon adopting the basic values of good governance like rule of law, corruption-free and smart (lean or smooth) administration, financial discipline, and efficient management of public work and resources to create situation for providing public services in speedy and cost-effective manner; by bringing into execution (enforcement) of the right of the citizens upon having good governance by translating it to practical reality; and transform the administrative mechanism into service delivery mechanism and facilitator; (Preamble the act). Here the preamble 
has clearly mentioned the objectives of act. In the preamble the term civil society has not been mentioned but civil society can perform their work for implementing good governance on the basis of these provisions.

\section{Basis for Executing Administrative Functions (Section: 6)}

The preamble of act initially mentions the public administration as major mechanism of maintaining and strengthening good governance. So the administrative functions managed under the act are very important in the implementation of good governance process. The act has managed ten major bases for executing administrative functions they are:

(a) Greater interest of nation and people;

(b) Equity and inclusiveness;

(c) Rule of law;

(d) Guarantee of the human rights;

(e) Transparency, objectivity, accountability and honesty;

(f) Economic (financial) discipline, corruption-free, lean (smart) and people--Oriented administration

(g) Impartiality and neutrality of administrative mechanism;

(h) Access of people to administrative mechanism and its decision;

(i) Decentralization and devolution of powers; and

(j) Popular participation and optimum utilization of local resources. (Section: 6).

These bases are the elements and principles of good governance determined in the context of Nepal. Major principles of good governance have been mentioned in the preamble but these bases are also considerable for the managing and operating good 
governance in Nepal.

\section{Consultation May be Made with Civil Society or Stakeholders while Implementing the Matters of Public Concern}

The act has aimed linking civil society and stakeholder into the process of implementing the matters of public concern. Really the matters of public concern can be addressed with the help of civil society. So the act has assimilated the provision of civil society as integrated part of the good governance. Act reads that- Government of Nepal may make necessary consultation with stakeholder and civil society, if necessary, before the implementation of any matter of public concern (section: 20). The consultation taken from civil society on public matters may give due attention by government while implementing the decision (section 20). It is the major provision made about civil society's role in the case of implementing good governance.

\section{Citizen's Charter to be Maintained}

The act has made provision relating to citizens' charter to be maintained. Now-a-days, in every public office we can see citizens charter which helps to service-holders about the service they are going to be taken. The provision of Citizen's charter to be managed in prescribed form and locate it in the visible place of the office is very important matter of this act. The citizen charter should contain the following matters;

(a) Detail statement of service offered by the office and its nature,

(b) Procedure to be followed by the service user (customer) to obtain the service,

(c) Estimated time for delivering the service, 
(d) Description of the officer responsible for providing service and his/her chamber,

(e) Particulars of the fees to be charged or other amount to be paid, if any, to receive the service,

(f) Other matters as prescribed

Locating citizen's charter has been made mandatory to all the offices and chief of the offices made responsible for locating it. The act has made the provision of compensation to the service user in case of failure of providing the services mentioned in the charter by public officials (section: 23). Code of conduct is not only legal responsibility but also moral duties. So rules of behavior are very significant in the case of operating good governance. In case of violation or noncompliance of code of conduct the concern authority must bear legal action and punished by prevailing laws in force. Civil society can play their role here by teaching people about the citizen's charter.

\section{Citizen's Charter}

Citizen's charter is generally the list of services to be delivered by concerned office. It makes it clear to the service users what kind of services they are going to obtain. Description of statement of services, procedure of obtaining services, estimation of time, particular fees and other important matters are major organs of citizen's charter to be maintained. The act has provisioned the following matters while locating the citizen's charter.

(a) Detail statement of service offered by the office and its nature,

(b) Procedure to be followed by the service user (customer) to obtain the service,

(c) Estimated time for delivering the service, 
(d) Description of the officer responsible for providing service and his/her chamber,

(e) Particulars of the fees to be charged or other amount to be paid, if any, to receive the service,

(f) Other matters as prescribed (Section: 25). Department action against the in-charge of concerned office in case the service user doesn't receive service and the amount of compensation for the loss incurred to the customer are also considerable matter while preparing and locating the citizen's charter. Fixing of reasonable service fees, mobile service to be operated, public participation and ownership in the project and program and establishment of governance reform unit for function, power and duties are also significant factors of public administration for operating good governance. Civil society can monitor whether people have been able to get these services or not on the basis of provisions made in the charter.

\section{Public Hearing}

About public hearing the act reads- Public hearing to be held : (1) The Chief office-holder at regional, zonal, district and local level involved in delivery of service, shall conduct public hearing as prescribed, with the purpose of making the activities of the office fair, transparent, and objective and addressing the lawful concerns of general people and stakeholders.

(2) While conducting public hearing pursuant to Sub-section (1) the expert of the related subject, stakeholder, and representatives of civil society and officials of the local bodies shall be invited.

(3) Notwithstanding anything contained in this Section, public hearing shall not be required to be held in the matters to be decided judicially (section: 30 ). 
Public hearing with civil society promotes good governance. And here the role of civil society has clearly addressed. Public hearing improves hurdles while operating good governance by public administration. Public hearing also makes the activities of the office fair, transparent and addressing the lawful concerns of service user or stake holders. Way of compliance and grievance management, not to encroaching on the authority of other officials, advisor as expert may be appointed to get advice for providing services and provision of spoke person to be appointed about the activities and functions carried out by the ministry, department, and governmental agency or office are also remarkable matters for operating good governance.

\section{Compliance of Act}

Compliance of good governance operation and management act is basic part of this act. This act not only operates on centre level but also on constitutional body, local body, regulatory body or public corporation under full or partial ownership or control of the Government of Nepal requiring to perform work. According to the constitution or prevailing laws and official working in these bodies or corporation, while performing their work, this act shall mutatis mutandis implement or cause to implement the provisions mentioned in Section 6, 7, 13, 14, 15, 16, 17, 18, 19, 20, 21, 22, 23, 24, 25, 26, 28 and 30. (section: 36). This provision clearly reads that all tiers of government including centre, provincial and local level must compliance the act and follow the provision relating to management and operation of good governance. So in all tiers of government and in constitutional bodies too civil society can play their respective roles in the process of implementation of good governance act. 


\section{Practice of Information Technology}

The provision of information technology is another provision of this act. e-governance and computer appliance in every offices is the product of this act. In the act it is managed that every ministry, department and government agency and office may bring computerized information technology into practice based on the availability of their resources and means (Section: 37). On the basis of these provisions civil society can play their prominent roles in the process of operating and managing good governance.

\section{Conclusion}

Civil society is generally voluntary organizations associated for welfare of state. It is associated on the ground of civic knowledge, civic education and civic virtue. Civil society works and plays its role in the democratic regime. Democratic regime operates on the basis of democratic norms and values. Such norms and values are incorporated in the Constitution. Constitution is a means providing place for civil society. Unions, associations, organizations, institutions and all networks can be included within the boundaries of civil society. In the case of assimilation of civil society people can be engaged for the welfare of society and community. Civil society can perform their effective work in the decision making and implementing process. Civil society teaches citizens on participation of people on democratic system. It can easily check on the performance of political parties and make them responsible to people. Civil society checks and controls the action of government contrary to interest of people. Civil society plays various roles in the society. Among them the role relating to maintaining, promoting and strengthening good governance is considerable for implementing democratic governance. Civil society plays various roles like, participating, 
mediating interest, mobilizing counter knowledge, influencing policy making, building commitment for public good, giving impetus to community building projects, motivating citizens, government towards co-operation, etc. It can play the communicative role, protective role, control role, socialization role, service delivery role and the global citizenship role in different cases. Major areas of good governance are democracy, rule of law, proprietary rights, corporate governance, human rights, welfare state and labor institution. And in these areas civil society can perform its respective roles. In the context of Nepal too our constitution has provided some space for civil society. Although, the needy legal provisions for implementing constitutional provisions relating to good governance have not been properly managed yet. Constitution of Nepal has incorporated more or less some provisions relating to the role of civil society in good governance system. The constitution has accepted the sovereign and state power of people. Such as, constitution has managed the important norms and values of democracy. Democracy is another name of good governance. In the constitution fundamental rights as a form of good governance has been provisioned, some provisions relating to civil society too have been mentioned there.

Nepalese parliament has promulgated the act named good governance operation and management act 2008. Here some provisions relating to civil society's role in operating and managing process has been mentioned. Matters included into the preamble of good governance operation and management act 2008 such as Practice of Information Technology, basis for executing administrative functions, consultation may be made with civil society and stakeholders while implementing the matters of public concerns, citizens charter to be maintained, public hearing to be conveyed, compliance of act to be applied 
in all tiers of government and constitutional bodies of Nepal and e-governance to be followed are some provisions relating to legal role of civil society in the process of operating and managing good governance in Nepal.

\section{References}

Anheier, K. (2000). How to Measure Civil Society.

Bratton, M. (1989). The Politics of Government-NGOs Relations in Africa in World Development, 17 (4), 569-587.

Clayton, A. ed. (1996). NGO, Civil Society and the State: Building Democracy in Transitional Societies. Oxford: Intrac.

Constitution of Nepal (2015). Kathmandu: Nepal Law Books Management Committee.

Dahal D. R. and Heinz B. (2008). Development Studies, Nepal: FES.

Dahal, D.R. (2006). Civil Society in Nepal: Their Roles in Conflict and Peace-Building, Kathmandu: UNDP Support for Peace and Development Initiative.

Diamond, L. (1999). Developing Democracy towards Consolidation, Baltimore and London: The Johns Hopkins University Press.

Diamond, L. (1994). Rethinking Civil Society: Toward Democratic Consolidation. Journal of Democracy 3, 4-17.

Gladwin, M. (1994). The Theory and Politics of Contemporary social Movements: Politics, 14, 43-65.

Good Governance Operation and Management Act (2007) Kathmandu: Nepal Law Books Management Committee 
Interim constitution of Nepal (2007). Kathmandu: Nepal Law Books Management Committee.

Khan, R. (2018). Civil Society and Good Governance, Pakistan: The Express Tribune.

Matena, C. (2010). Good Governance and Civil Society, New York : Springer Link.

Migdal, JS. (1988). Strong Societies and Weak States: Statesociety Relations and Capabilities in the Third World. Princeton, NJ: Princeton University Press.

Paffenholz (2009). Civil Society and Peace Building, Switzerland: CCDP.

Paffenholz, T. and Christoph, S. (2006). Civil Society, Civil Engagement and Peace Building. Social Development Papers, Conflict Prevention and ReConstruction, Washington: World Bank.

Pearce, J. (2005). The International Community and Peace Building, Development. 48, 41-49. 